\title{
Level of fisheries development and its impact on the socio-economic development of the region
}

\author{
Andrey Novikov ${ }^{1, *}$, Anna Pakhomova ${ }^{1}$ \\ ${ }^{1}$ Institute of service and business (branch) of DSTU in Shakhty, 147, Shevchenko str., 346500, \\ Shakhty, Russia
}

\begin{abstract}
The fishery complex of the Russian Federation, due to its natural and climatic conditions, has tremendous potential both for saturating the food market with high-quality products and for the socioeconomic development of the region due to the creation of a large number of highly paid working places and conditions for the provision of services for organizing sports fishing. One of the largest fishery complexes in the Russian Federation is Rostov region where biological resources are extracted by fishery enterprises in the Azov and Black Seas, Taganrog Bay, Tsimlyansk, Veselovsky and Proletarsky reservoirs and numerous pond farms, the capabilities of which are not fully used. Oktyabrsky district has enormous resources of pond fishing and fish farming. On the example of this region, one can observe the influence of all the shortcomings that impede the further increase in the level of development of the fishing industry. The elimination of these shortcomings will not only increase this level, but also contribute to the socio-economic development of the region.
\end{abstract}

\section{Introduction}

The fishery industry is one of the traditional industries of Russia. Fishery in the Russian Federation is the economic sector that includes a range of different types of activities, from forecasting the raw material base of the industry to organizing fish products trade in the country and abroad.

The fishery industry has a significant impact on the economy of the country, being, on the one hand, a source of quality food and, on the other hand, a source of elemental base for cosmetic, pharmacological and chemical industries.

In maintaining food security of the country, a fishery complex plays an important role. According to the Food Security Doctrine of the Russian Federation, approved by Decree of the President of the Russian Federation dated January 30, 2010 No. 120, one of the most important tasks of the Russian fishery complex is to strengthen the food security of the country, as well as to provide the population with domestic fish products [1].

Unfortunately, contemporary studies devoted to this problem mainly concern the

\footnotetext{
"Corresponding author: novikov-1962@bk.ru
} 
extraction of marine biological resources and do not consider the development of pond fishing and fishery farming.

In this article, the authors address this issue, since it is relevant for Rostov region, which has both marine and pond biological resources.

\section{Results}

The resource base of domestic fishery has significant potential for increasing the volume of extraction (catch) of aquatic biological resources. The stocks of the main commercial species of aquatic biological resources are in a steady state. At the same time, the intensity of biomass exploitation for the main facilities for which the total allowable catch is established does not exceed the limit level. Most of the developed aquatic biological resources have scientifically based high assessment of the reserves sustainability. For certain types of aquatic biological resources, reserves are subjected to cyclical fluctuations due to natural biological causes.

Globally, the Russian Federation is among the top five world leaders in terms of production of marine and pond biological resources. The main share is cod species of fish (cod, haddock, pollock, blue whiting, saida). Russia occupies a leading position in world production (catch) in certain groups of aquatic biological resources (cod is $29 \%$, salmon is 52 , herring is $4.2 \%$ ). At the same time, up to $71 \%$ of production made by Russian enterprises falls on the exclusive economic zone and the continental shelf of the Russian Federation, 16 - on the exclusive economic zones of foreign states, 13\% - on the territorial sea, inland waters, open areas of the World Ocean and areas of operation of international fishery conventions and conservation of aquatic biological resources.

The detailed assessment of aquaculture, the current state of fisheries in the Rostov region is analyzed in the paper.

According to data of Russian fisheries, Rostov region is $18^{\text {th }}$ among 80 fishing entities of Russia in terms of fish caught and other aquatic biological resources, yielding to regions with access to seas or ocean and specializing in fish processing.

Currently, in Rostov region there are more than 300 enterprises operating in the field of aquaculture, including pond, industrial and pasture fish farming. Let us analyze the institutional structure of fishing enterprises (Fig. 1).

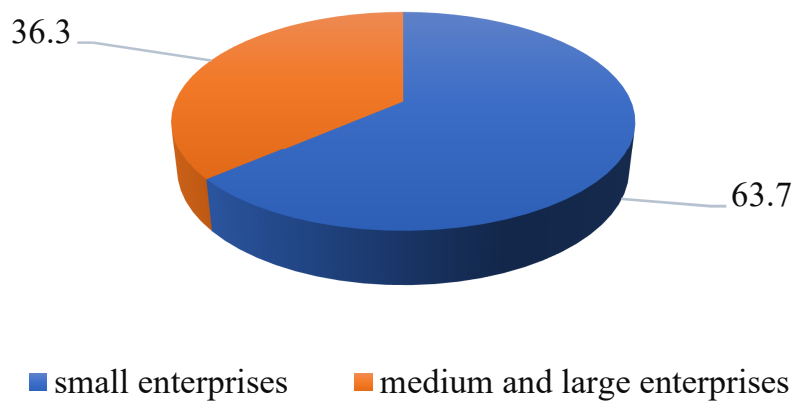

Fig. 1. Institutional structure of enterprises engaged in fishing in Rostov region, as a percentage.

It can be seen from the above figure 1 that fishing is mainly carried out by small enterprises and they constitute $63.7 \%$ in the overall structure of enterprises.

Over the years Rostov region has maintained a leading position in the production of commercial fish. The volume of production of commercial fish in Rostov region in 2019 
amounted to 24.4 thousand tons, which is $3.8 \%$ more compared to the same period last year (Figure 2).

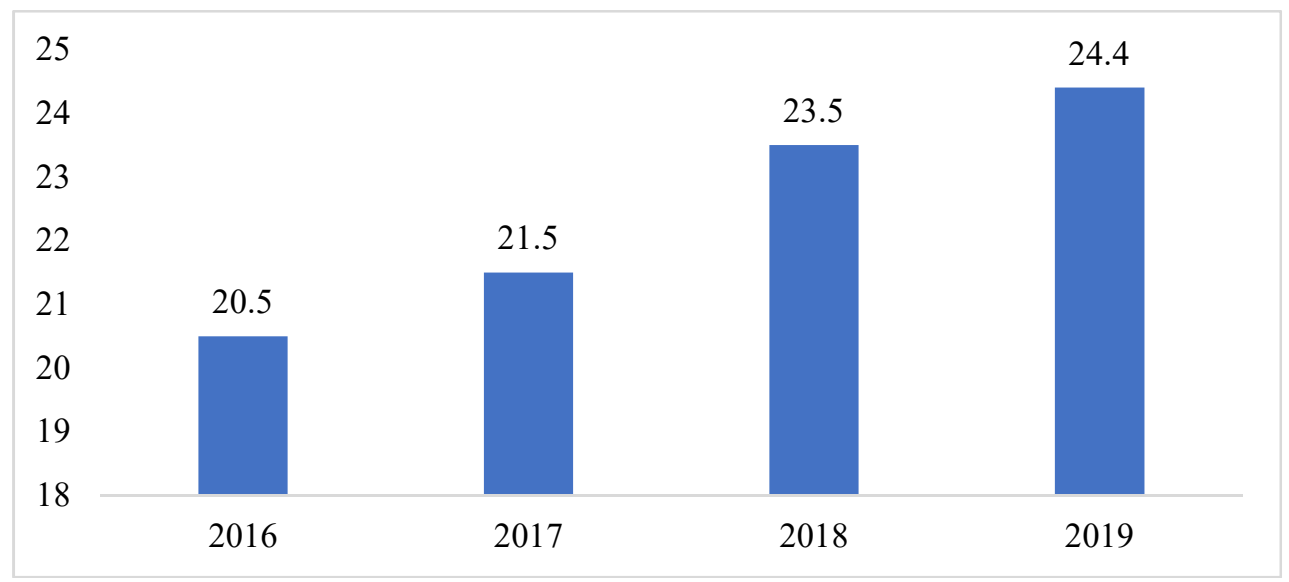

Fig. 2. Volume of commodity production in Rostov region for 2016-2019, thousand tons.

Thus, we can conclude that aquaculture is dynamically developing in Rostov region. The result of the fish farms work is to provide the population of Rostov region and other regions with high-quality fish products.

According to official statistical information, the main source of fish industry production is live fish production. In Rostov region industrial fishing is carried out by fishery enterprises in the Azov and Black Seas, Taganrog Gulf, Tsimlyansky, Veselovsky and Proletarian reservoirs. Figure 3 shows the dynamics of the volume of catches of biological resources in Rostov region for 2016-2018.

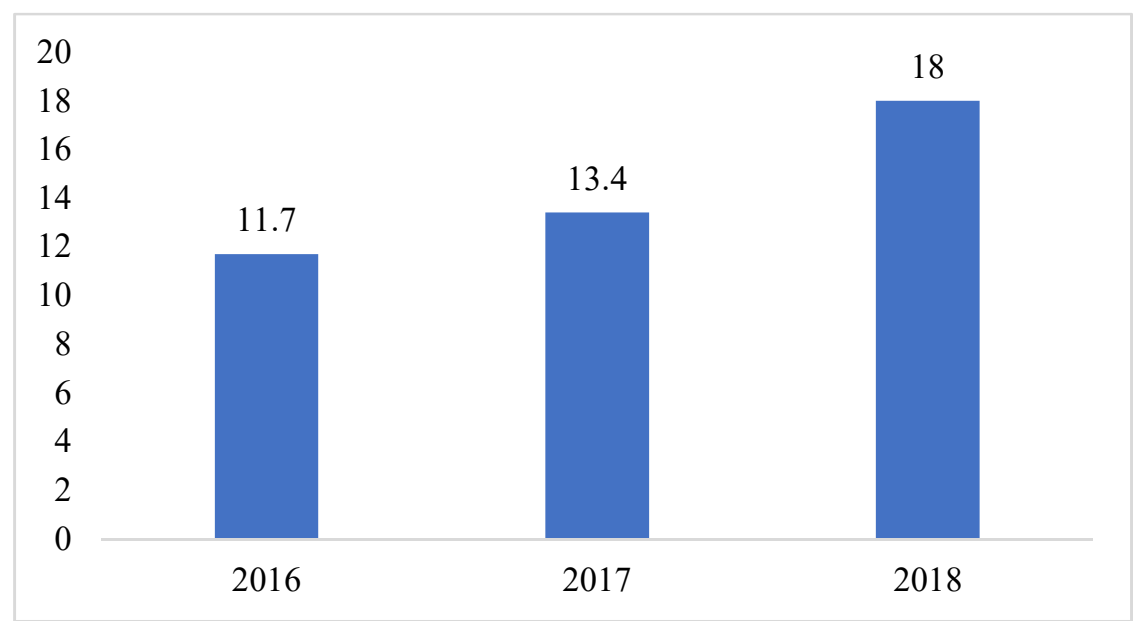

Fig. 3. Volume of catches of biological resources in Rostov region for 2016-2018, thousand tons.

The volume of production of aquatic biological resources in 2018 amounted to 18.0 thousand tons, which is $34.3 \%$ more than the same period last year. An increase in the production of aquatic biological resources occurred in connection with the acquisition of two vessels of the fishing fleet.

In the production of live freshwater fish, Rostov region is on second place among the fish-producing entities of Russia, after Krasnodar Territory. Over the past three years, the extraction of live freshwater fish, as well as fish farming products, in Rostov Region has 
averaged 9 thousand tons. Figure 4 shows the structure of production of fisheries in Rostov region for 2016-2017.

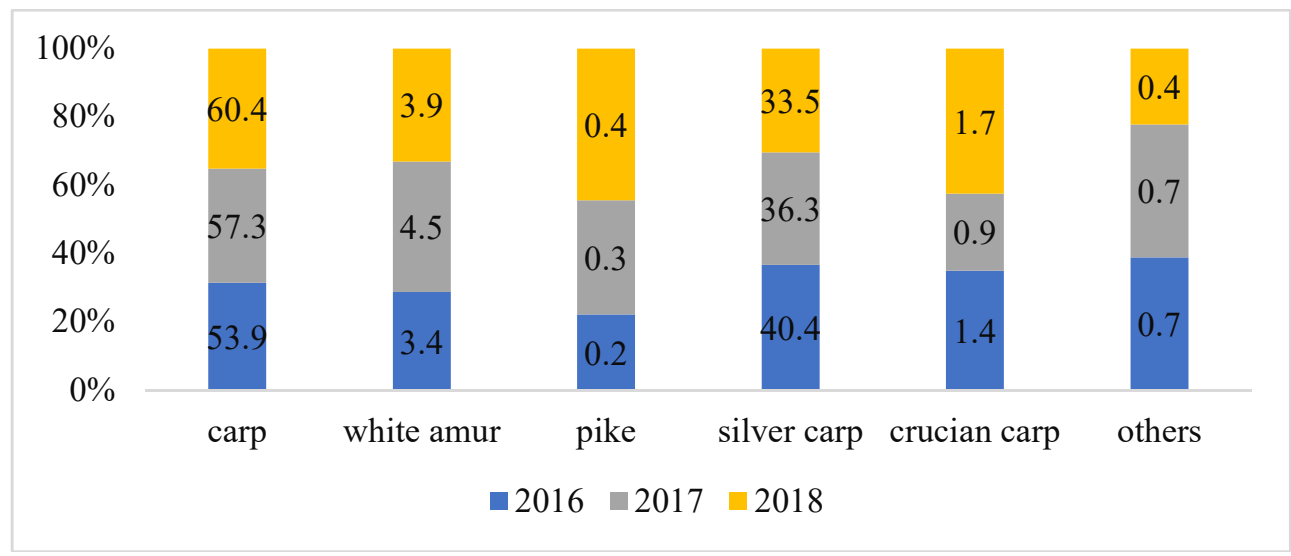

Fig. 4. The structure of fishery production in Rostov region for 2016-2018, as a percentage.

Today, in Rostov Region there are more than 40 enterprises engaged in the extraction of water biological resources and fish processing, to produce the following products: dried fish, smoked, salted, balyk fish, vacuum-cut fish, preserves, canned fish, and fish snacks. The dynamics of the volume of processed fish products is presented in Fig. 5.

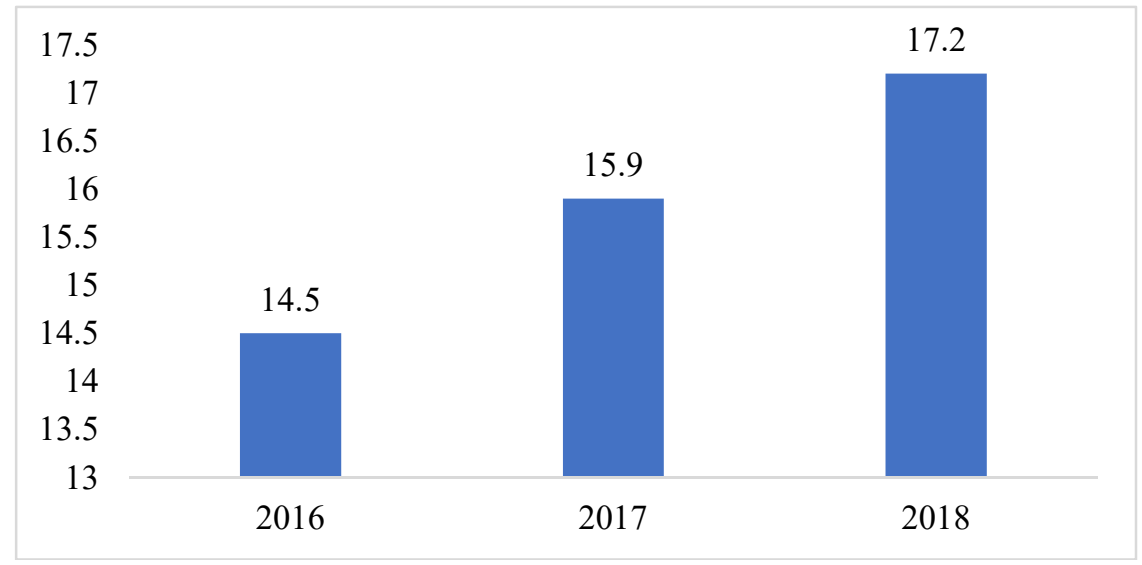

Fig. 5. Volume of processed fish products in the Rostov region for 2016-2018, thousand tons.

It can be seen from the above stated figure that the volume of processed fish products in 2018 amounted to 17.2 thousand tons, which is $8 \%$ more than the same period last year.

Every year activities on artificial reproduction of water biological resources are carried out in Rostov region. In modern conditions, artificial reproduction carried out by fishgrowing enterprises is the main source of replenishment and restoration of migratory (sturgeon, stellate sturgeon, vimba, shamay) and semi-migratory (pike perch, bream, carp) fish species. The volume of production of juvenile fish is currently influenced by: the provision of enterprises with producers, including those harvested in a natural reservoir; technical equipment of breeding and spawning farms. One of such enterprises is Don Sturgeon Factory, where since 2004, young sturgeon, Russian sturgeon, stellate sturgeon have been produced, grown and released into a natural reservoir in order to maintain the population.

From the above pointed facts it can be concluded that Rostov region has sufficient 
potential of fishing industry.

\section{Discussion}

There is no doubt that the level of development of fisheries and fish farming has a significant impact on the socio-economic situation in the region. The authors of the article appeal to pond biological resources of Oktyabrsky district of Rostov region as the object of study.

As a leitmotif it is possible to use the words of the Governor of Rostov region V.Yu. Golubev "The feature of Oktyabrsky district is the correct position of the head creating conditions for investors to come to the district. Very notable projects have already been implemented here and they are supposed to have good prospects.

These words of the Governor of Rostov region Golubev V.Yu. quite eloquently characterize the attitude towards the regional leader and the level of social and economic development of the region. Indeed, there is no doubt that Oktyabrsky district is currently one of the most dynamically developing regions of Rostov region in the South of Russia

Its investment attractiveness is due not only to logistical advantages (as it is located in the center of Rostov Region), but also to its rich natural resources, historical and cultural heritage, high-tech industries, and the possibilities of training highly qualified specialists in the best educational institutions of the region It can be argued that one of the most effective sectors in the region is poultry farming, the level of development of which, first of all, should be assessed by the activities of such flagships as the turkey-breeding complex Eurodon LLC, Illichivsk Poultry Poultry Farm and Markinsky Poultry Farm.

On the other hand, it is obvious that the region has the potential for the development of other industries. Such perspective industry activities can be activities related to fish farming, fishing and fishing tourism. The analysis of the fish assortment in the shops of Oktyabrsky district and the nearby towns Shakhty and Novocherkassk prompted the authors to turn to the problems of fishing industry development. The products here are represented by Tsimlyansk bream, Semikarakorsk carp and even Armenian crayfish. The same situation is in the market of dried, smoked, salted and canned fish.

This article is aimed at assessment the possibilities of developing fish farming and fishing in Oktyabrsky district in modern economic conditions. Fishery plays a crucial role in solving the problems of providing the population with high-quality food products, especially animal proteins. Of the total fish catch, more than two-thirds are products of marine and oceanic origin.

Appealing to the problem of the development of pond fishing and fish farming it should be pointed out that it is also associated with nutritional value and quality of fish. Obviously, fish is a high-protein raw material for cooking a lot of different dishes. The protein content in fish ranges from $16.7 \%$ to $21.6 \%$, and the same indicator for the most common types of meat and poultry ranges from $14.4 \%$ to $20.8 \%$, while even a small amount of fish protein fully meets the need of the human body for amino acids such as phenylalanine and threonine.

Here we would like to focus on the advantages of fish production, and, above all, carp is supposed to be important due to the taste qualities and benefits compared with sea bass and dorado which are well known from mass media. The classic representative of pond fish is carp, which is absorbed by the human body by $92-93 \%$. Not being specialists in the field of dietetics, but being the lovers of carp, the authors of the article agree with Sklyarov G. A. [3], who gives the following characteristics as shown in Table 1. 
Table 1. Comparative chemical composition of fish meat.

\begin{tabular}{|l|c|c|c|c|}
\hline \multirow{2}{*}{ Fish species } & \multicolumn{4}{|c|}{100 g of meat contains on average.\% } \\
\cline { 2 - 5 } & water & protein & fat & salt \\
\hline Fat carp & 74.0 & 16.8 & 8.0 & 1.2 \\
\hline Thin carp & 79.6 & 18.5 & 0.9 & 1.0 \\
\hline trout & 75.6 & 21.5 & 2.6 & 1.3 \\
\hline White amur & 76.4 & 18.5 & 4.0 & 1.1 \\
\hline White silver carp & 75.9 & 16.9 & 5.9 & 1.3 \\
\hline Motley silver carp & 73.8 & 17.7 & 7.1 & 1.4 \\
\hline
\end{tabular}

Taking into account the fact that the largest water arteries of Oktyabrsky district are the Don and Aksai rivers, the problem of fishery pond economy development is primarily relevant for the region.

It can be argued that the region has significant natural and economic potential for the development of fish farming. This can be confirmed by the activities of such enterprise as Novocherkassk Fish Plant LLC, which is the largest full-system complex for the production of live fish in Russia and Europe with a water mirror area of 4,250 hectares.

The main type of activity of NFP LLC is the production of live marketable fish, fish stocking material and the sale of fish to legal entities and population, including live-fish motor transport of the enterprise. The area where the complex is located is rich in natural water resources; these are more than 10 small rivers (eriks), tributaries of the Don and Aksai and more than 20 natural lakes.

This geographical location of the complex allows maintaining a high ecological balance of water and land resources. The territory of the complex is rich in diverse flora and fauna. The complex has constantly replenished deposits of highly fertile bottom silt used for production of nutritious soils and recultivants. Bottom silts of the plant have balanced agrochemical indicators of quality and biological safety. Fertile soils based on the bottom silts of the plant, are ideal for agricultural enterprises in arid regions. Other enterprises involved in the production of fish also have great opportunities [6].

Thus, a contradictory picture can be observed: enterprises capable of providing pond fish with a whole region do not dominate even in local markets. Obviously, the producers themselves can be blamed for this state of affairs. But it is necessary to outline specific ways out of this situation.

The adoption and implementation of Oktyabrsky District Fishery Development Program should be considered as one of such ways. Currently, the concept of development of Russian fisheries for the period up to 2030 is being implemented on the territory of our country.

However, it is not possible to use it to develop a similar document for Oktyabrsky District, since the main provisions of this concept are devoted to the development of marine and ocean fisheries. Considering the possibility of developing Oktyabrsky District Fishery Development Program, the main factors to impede the development of fisheries in the region should be highlighted. These factors include:

-low efficiency of municipal administration in the field of fisheries;

- lack of thecompetitive institutional environment that stimulates the attraction of capital in the economy of fisheries;

- lack of necessary conditions for structural diversification and innovative development of the fishery complex;

- low level of competition, which does not create incentives for organizations to increase labor productivity and competitiveness;

The increase in the illegal fishing of aquatic biological resources. 


\section{Conclusions}

Based on the priorities of socio-economic development of Oktyabrsky district for the near future and the above-mentioned problems, the strategic goal is to achieve a level of fishery development to occupy advanced positions.

Achievement of this goal provides for the transition of the development of the fishery complex to an innovative type of development based on the conservation, reproduction, rational use of aquatic biological resources and the competitiveness generated by the regional fishery complex of goods and services.

Achievement of the strategic goal of development of fisheries of Oktyabrsky district requires the formation of an integrated approach to management of industry development, realization of coordinated measures by resources, terms, stages of transformation and providing the solution of the following tasks [3]:

- improving the regulatory framework in the field of fisheries, consistent with its effective development;

- ensuring effective municipal administration in the field of fisheries;

- creating a highly competitive institutional environment that stimulates entrepreneurial activity and attracting capital to the fishery economy;

- ensuring the rational use of aquatic biological resources, taking into account the fishing load on these resources;

- the development of artificial reproduction of aquatic biological resources, as well as the formation of gene pool collections and brood stocks of valuable species of aquatic biological resources;

- improving the system of protection of aquatic biological resources and their habitat, as well as ensuring effective control and supervision of aquatic biological resources and their habitat;

- expansion of research and development in the field of fisheries, as well as the development of scientific and technical potential and the system of educational institutions of the fishery complex;

- technical potential and the system of educational institutions of the fishery complex;

- the creation of new technologies for the extraction of aquatic biological resources, deep and integrated processing of raw materials, as well as the improvement of storage and transportation of fish products;

- development of fish processing capacities and strengthening the position of enterprises in the region in the market of fish products based on increasing the degree of processing;

- development of the sector of intellectual services in fisheries, including management and financial consulting, auditing, engineering services, services in the field of marketing, branding and development of public relations.

Successful solution of these tasks will allow:

- saturate the markets with inexpensive high-quality products in the form of live, chilled, smoked, dried fish, processed foods and canned foods, which will significantly expand the consumer basket of Russian people with different income levels;

- load food capacities by fish processing enterprises in the region;

- create an additional number of working places;

- create conditions for the development of paid and sport fishing.

\section{References}

1. Food Security Doctrine of the Russian Federation (ReedGroup, Moscow, 2011)

2. The development strategy of the fishery complex of the Russian Federation for the 
period until 2030 (FGBNU "Roinformagroteh", Moscow, 2019)

3. Ecological mechanisms underlying the sustainability of the agricultural heritage ricefish coculture system (PNAS, 2011)

4. G. Sklyarov, Fish farming (Phoenix, Rostov n/D, 2013)

5. Ministry of Agriculture of the Russian Federation: Concept for the development of fisheries of the Russian Federation for the period until 2020, www.mcx.ru/documents/document/show/6409.191.htm

6. Rostov Region - movement towards sustainable development goals (Rostov $\mathrm{n} / \mathrm{D}, 2019$ )

7. Importance of fisheries to man, www.worldoceannetwork.org/won-part-6/ carem-wod2014-4/ocean-important/facts-figures/

8. Magnuson-Stevens Fishery, Conservation and Management Act (National Acad. of Pablic Admin. Woot. Pofl. Center. Fedex., New York, 2008)

9. Regional review on status and trends in aquaculture development in Europe-2010 (FAO Fisheries and Aquaculture Circular, 2011)

10. The State of World Fisheries and Aquaculture. Meeting and sustainable development goals (FAO of UN, 2018)

11. D. Lysakovskaya, Economics and Environmental Management 1, 262-267 (2012)

12. A. Bogachev, Vestnik Niiei 5(84), 110-121 (2018)

13. N. Dubinina, E. Karlina, Bulletin of the Astrakhan State Technical University, Series: Economics, Fisheries Development Potential in Russia: Analytical Aspect 3, 79-88 (2017)

14. S. Lachininsky, A. Shendrik, N. Petukhova, Bulletin of the Baltic Federal University, Series: Natural and Medical Sciences, Current State and Problems of the Development of Fisheries in the Maritime Regions of the Russian Federation 4, 5-20 (2019)

15. Y. Kuranov, Bulletin of MSTU 18, 447-453 (2015) 